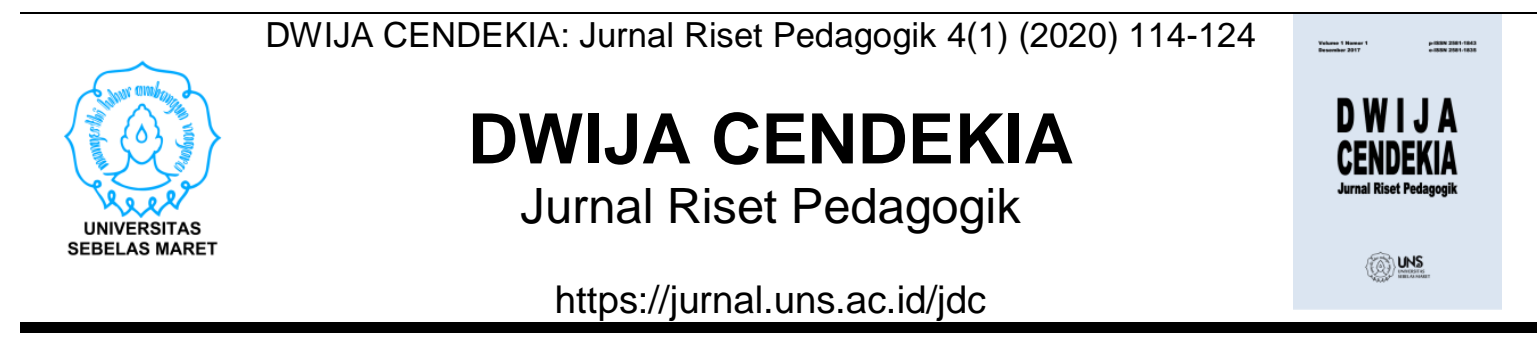

\title{
How E-Learning Affects Students' Mental Health During Covid-19 Pandemic: An Empirical Study
}

\author{
Siti Fatimah', Umi Mahmudah² \\ ${ }^{1}$ Universitas Sebelas Maret, ${ }^{2}$ Institut Agama Islam Negeri Pekalongan \\ stfatimah89@gmail.com
}

\section{Sejarah Artikel}

diterima 06/06/2020

disetujui 26/08/2020

diterbitkan 31/08/2020

\begin{abstract}
This study aimed to determine the impact of e-learning on the Indonesian students' mental health during the COVID-19 pandemic. The subjects in this study were 210 respondents, namely students at the junior high school, senior high school, and university levels. The instrument used was both closed and open questionnaire sheets. The data analysis technique was multiple linear regressions using the Ordinary Least Square (OLS) method. The analysis shows that: 1) e-learning has a positive and significant effect on mental health; 2) age has a positive but is not statistically significant effect on mental health; and 3) gender has a negative but is not statistically significant effect on mental health.

Keywords: E-learning, mental health, COVID-19
\end{abstract}

\begin{abstract}
Abstrak
Penelitian ini bertujuan untuk mengetahui pengaruh e-learning terhadap kesehatan mental siswa di Indonesia saat pandemi COVID-19. Subjek dalam penelitian ini berjumlah 210 responden yaitu siswa pada tingkatan SMP, SMA, dan Universitas. Instrumen yang digunakan berupa lembar angket tertutup dan terbuka. Teknik analisis data yang digunakan menggunakan regresi linear berganda dengan menggunakan metode Ordinary Least Square (OLS). Hasil analisis menunjukkan bahwa: 1) e-learning memiliki pengaruh yang positif dan signifikan terhadap kesehatan mental; 2) usia memiliki pengaruh yang positif dan tidak signifikan terhadap kesehatan mental; dan 3) gender memiliki pengaruh yang negatif dan tidak signifikan terhadap kesehatan mental.

Kata kunci: E-learning, kesehatan mental, COVID-19
\end{abstract}

e-ISSN 2581-1835

p-ISSN 2581-1843

This work is licensed under a Creative Commons Attribution-ShareAlike 4.0 International License. 


\section{PENDAHULUAN}

Pandemi COVID-19 yang saat ini masih berlangsung di hampir seluruh negara di dunia, termasuk Indonesia, merupakan pandemi yang memiliki dampak global yang cukup besar. Pada 2 Maret 2020, kasus pertama COVID-19 terdeteksi di Indonesia; pada 8 Mei lebih dari 12.776 kasus dan 930 kematian telah dilaporkan di semua 34 provinsi. Namun, studi permodelan memperkirakan bahwa hanya 2 persen dari semua infeksi telah dilaporkan. Tanpa pengobatan atau vaksin yang tersedia, Indonesia dan negara-negara lain mengandalkan jarak fisik untuk memperlambat penyebaran virus (www.unicef.org). Isolasi, pembatasan kebijakan dan penutupan ekonomi memaksakan perubahan total pada lingkungan psikososial di negara-negara yang terkena dampak. Langkah-langkah ini berpotensi mengancam kesehatan mental anak-anak dan remaja secara signifikan. Kecemasan, kurangnya kontak dengan teman sebaya dan berkurangnya peluang untuk pengaturan stres adalah masalah utama. Ancaman utama lainnya adalah peningkatan risiko penyakit mental orang tua, kekerasan dalam rumah tangga dan penganiayaan anak. Terutama untuk anak-anak dan remaja dengan kebutuhan khusus, seperti cacat, trauma pengalaman, sudah ada masalah kesehatan mental, dan status sosial ekonomi rendah (Fegert, et al., 2020).

Salah satu dampak yang sangat dirasakan dengan adanya pandemi COVID-19 adalah sistem belajar daring yang dilakukan oleh seluruh lembaga pendidikan di Indonesia bahkan seluruh dunia. Pembelajaran daring menjadi satu-satunya solusi agar sistem pembelajaran tetap berjalan. Pendampingan dari orang tua ke anak menjadi salah satu kunci keberhasilan dalam pembelajaran daring yang dilakukan. Pendampingan yang maksimal dari orang tua akan memudahkan anak untuk memahami materi. Namun, pembelajaran daring bukanlah aktivitas pembelajaran yang mudah untuk dilakukan bagi guru, siswa, dan orang tua karena hal ini merupakan hal yang baru. Meskipun hampir $66 \%$ keluarga telah memiliki akses internet, pembelajaran dengan mengunakan sistem online tetap menjadi tantangan bersama. Selain itu, penelitian UNICEF baru-baru ini menemukan bahwa banyak remaja, terutama perempuan, merasa bahwa mereka tidak memiliki keterampilan digital (www.unicef.org).

Kurangnya kesiapan dari guru, siswa, dan orang tua menyebabkan pembelajaran daring (belajar di rumah) kurang menyenangkan. Hal ini diperjelas dengan adanya survey yang dilakukan oleh Komisi Perlindungan Anak Indonesia (KPAI) tentang pembelajaran jarak jauh (PJJ) dengan 1.700 responden. Hasil survey menunjukkan dari 1.700 responden, sebanyak $77,8 \%$ responden menyatakan bahwa adanya tugas yang menumpuk karena seluruh guru memberikan tugas dengan waktu yang sempit. Sedangkan $37,1 \%$ responden mengeluhkan waktu pengerjaan tugas yang sempit sehingga membuat siswa kurang istirahat dan kelelahan. Sebanyak 42,2\% responden menyatakan tidak memiliki kuota internet dan $15,6 \%$ responden 
tidak memiliki fasilitas yang memadai seperti laptop atau handphone yang spesifikasi memadai untuk belajar daring. Survey juga menghasilkan bahwa interaksi antara guru dan siswa hanya sebesar $20,1 \%$ dan itu hanya sebatas pemberian tugas dari guru ke siswa. Sebanyak 79,9\% responden menyatakan, interaksi belajar mengajar seperti pada ruang kelas sudah hilang. Tidak ada interaksi belajar seperti tanya jawab dan penjelasan materi dari guru.

Adanya pembelajaran daring ini membatasi anak-anak untuk beraktivitas dan berinteraksi sosial sehingga mengakibatkan dampak yang kurang baik terhadap pendidikan dan perkembangan anak. Mekonnen, et al. (2020) menyebutkan bahwa salah satu aspek yang sangat penting dalam perkembangan anak adalah kesehatan mental. Dalam studi dari negara-negara berpenghasilan tinggi, gejala emosi dan gangguan perilaku anak (EBD) dikaitkan dengan adaptasi sosial yang lebih buruk, gangguan kesejahteraan fisik, gangguan fungsional dan hasil pendidikan yang lebih buruk. Fegert, et al. (2020) menyebutkan bahwa adanya COVID-19 memberikan banyak tekanan pada anak-anak, remaja dan keluarga mereka yang dapat mengakibatkan kesusahan, masalah kesehatan mental dan kekerasan. Stigma dan diskriminasi terkait COVID-19 dapat membuat anak-anak lebih rentan terhadap kekerasan dan tekanan psikososial. Hal ini sesuai dengan pernyataan dari IASC (2020) yang menyatakan bahwa ketika terjadi wabah apapun, orang-orang cenderung merasa khawatir dan tertekan. Diantara beberapa kekhawatiran dan ketakutan mereka adalah 1) takut jatuh sakit dan kemudian meninggal, 2) merasa tidak berdaya, 3) merasa bosan dan kesepian, dan lain sebagainya (IASC, 2020). Selain itu, IASC (2020) juga melaporkan bahwa diskriminasi dan stigma sosial masih sering dikaitkan dengan COVID-19 misalnya terhadap orang-orang yang dinyatakan positif COVID-19 beserta keluarganya. Bahkan, tenaga kesehatan yang merupakan garda terdepan dalam penanganan COVID19 pun tidak lepas dari stigma dan diskriminasi sosial tersebut.

Tekanan psikologi (mental) atau yang biasa disebut dengan Mental Health and Psychosocial Support (MHPSS) biasa digunakan dalam Pedoman Inter Agency Standing Committee (IASC) bertujuan untuk melindungi atau mempromosikan psikososial kesejahteraan dan / atau mencegah atau mengobati kondisi kesehatan mental. IASC merekomendasikan tingkatantingkatan level yang terintegrasi dalam kegiatan darurat COVID-19. Level-level ini selaras dengan spektrum kesehatan mental dan kebutuhan psikososial dan diwakili dalam piramida intervensi (Lihat Gambar 1) yaitu mulai dari menanamkan pertimbangan sosial dan budaya dalam layanan dasar, hingga menyediakan layanan khusus untuk individu dengan kondisi yang lebih parah. 


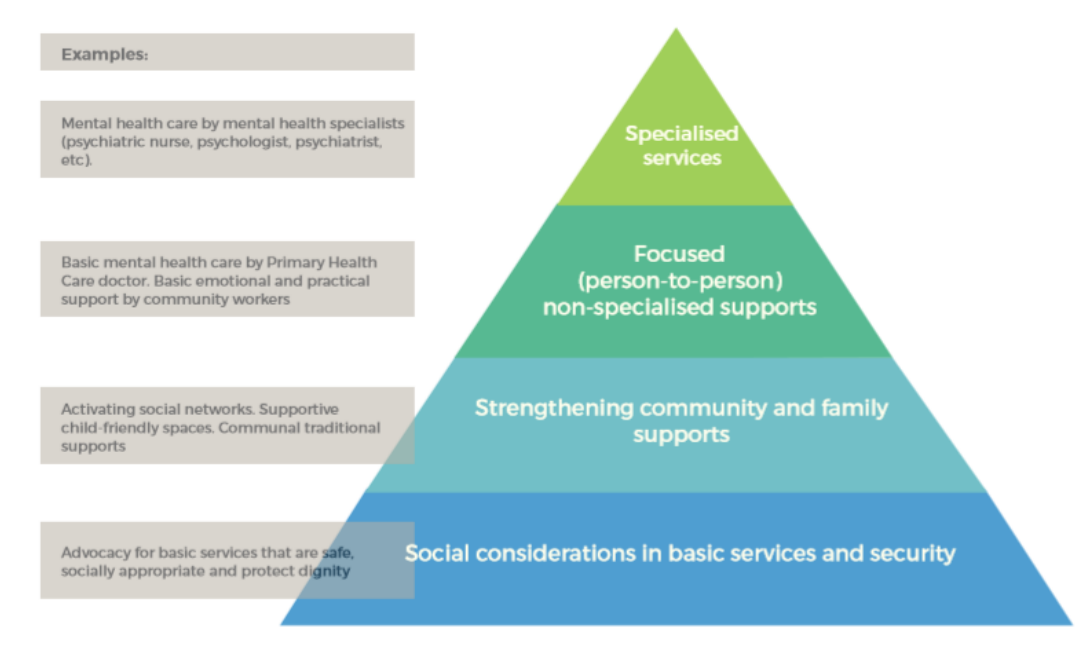

Gambar 1. Intervention pyramid for mental health and psychosocial support

(Source: www.unicef.org)

\begin{tabular}{|c|c|}
\hline $\begin{array}{l}\text { Kesehatan mental adal } \\
\text { omponen utama } \\
\text { erkembangan anak yang mam } \\
\text { lendorong anak-anak untuk belaj } \\
\text { Imbuh, dan menjalani kehidup } \\
\text { ang sehat dan produl } \\
\text { vww.nccp.org). Kesetahan men } \\
\text { vencakup kesejahteraan emosion } \\
\text { sikologis, dan sosial setiap indivi }\end{array}$ & $\begin{array}{l}\text { mendukung, mendengarkan, } \\
\text { memberikan cinta dan perhatian } \\
\text { ekstra; b) Berikan waktu luang bagi } \\
\text { anak untuk bermain dan bersantai; c) } \\
\text { Menjaga anak-anak agar tetap dekat } \\
\text { dengan orang tua dan keluarga; d) } \\
\text { Membuat jadwal dan kegiatan secara } \\
\text { rutin dengan aman dan santai; e) } \\
\text { Memberikan penjelasan kepada anak } \\
\text { tentang fakta yang telah terjadi, } \\
\text { jelaskan yang sedang terjadi sekarang } \\
\text { dan berikan informasi yang jelas } \\
\text { tentang cara mengurangi risiko } \\
\text { terinfeksi oleh penyakit/virus dengan }\end{array}$ \\
\hline
\end{tabular}
mulai dari masa kanak-kanak dan remaja hingga dewasa (www.mentalhealth.gov). Kesehatan mental yang positif memungkinkan orang untuk menyadari potensi diri secara penuh, mampu mengatasi tekanan hidup, dapat bekerja secara produktif, dan memberikan kontribusi yang berarti bagi orang lain.

WHO (2020) merekomendasikan beberapa cara yang dapat dilakukan orang tua untuk mengurangi stress pada anak selama COVID-19 yaitu: a) Menanggapi reaksi anak dengan cara

Pandemi COVID-19 tidak hanya berdampak pada kesehatan fisik namun kesehatan mental seseorang menjadi sangat rentan. Siswa yang mengalami perubahan drastis dalam proses pembelajaran juga rentan mengalami gangguan kesehatan mental. Dengan demikian, besarnya dampak kesehatan mental akibat pandemi COVID-19, terutama pada siswa sangat penting untuk dianalisis. Dampak pembelajaran e-learning, yang menjadi pilihan utama dalam 
proses belajar mengajar selama masa dianalisis dengan komprehensif. Dengan demikian, baik siswa maupun guru/dosen dapat menerapkan strategi yang paling baik dan terstruktur secara rapi dalam menata psikologis siswa selama pembelajaran pandemi COVID-19, perlu dengan e-learning. Penelitian ini diharapkan dapat dijadikan sebagai bahan kajian dalam rangka mengurangi tekanan mental pada siswa khususnya dalam pembelajaran daring.

\section{METODE}

Penelitian ini merupakan penelitian survey dengan subyek penelitian berjumlah 210 responden yang berada di tingkat pendidikan SMP, SMA, dan Universitas di Indonesia. Adapun teknik pengampilan sampel yang digunakan adalah purposive sampling, yaitu teknik sampling yang dilakukan berdasarkan pertimbangan-pertimbangan tertentu dari peneliti seperti dengan cara menentukan ciri khas yang sesuai dengan tujuan penelitian (Mahmudah, 2020). Sedangkan penyebaran angket dilakukan dengan menggunakan google form yang khusus ditujukan pada siswasiswa di tingkat SMP, SMA, dan Universitas. Pendistribusian angket dilaksanakan pada $22 \mathrm{Mei}-3$ Juni 2020.

Instrumen pengukuran kesehatan mental diadaptasi dari Brief Symptom Inventory (BSI) yang dikembangkan oleh Derogatis, L. dengan jumlah 22 item pernyataan. Teknik analisis data menggunakan regresi linear berganda dengan metode Ordinary Least Square (OLS). Uji validitas dan reliabilitas instrumen penelitian perlu dilakukan untuk memastikan bahwa item-item pernyataan dalam penelitian telah mewakili setiap variabel yang digunakan, yaitu pembelajaran $e-$ learning $(X)$ dan kesehatan mental (Y). Berdasarkan uji validitas insrummen dengan program SPSS menggunakan metode korelasi product-moment didapatkan bahwa semua item dinyatakan valid, dimana nilai signifikansi pada output SPSS untuk semua item pernyataa adalah lebih kecil dari 0,05. Sementara itu, uji reliabilitas instrumen dengan menggunakan SPSS memberikan hasil nilai Alpha Cronbach masingmasing 0,858 dan 0,884 untuk variabel $X$ dan variabel $Y$. Angkaangka tersebut mengindikasikan bahwa instrumen yang digunakan untuk mengukur variabel $X$ dan variabel $Y$ dapat dikatakan reliable secara statistika.

\section{PEMBAHASAN}

Penelitian ini menggunakan sebanyak 210 responden yang terdiri siswa SMP, SMA, dan mahasiswa di perguruan tinggi. Gambaran umum responden yang menjadi sampel dalam penelitian ini adalah sebagai 
berikut. Rata-rata usia responden dalam penelitian ini adalah 17 tahun dengan standar deviasi 3 tahun. Usia paling muda responden adalah 12 tahun sedangkan usia paling tua adalah 25 tahun. Mayoritas responden berjenis kelamin perempuan, yaitu sebesar $76.70 \%$ dibandingkan dengan responden yang berjenis kelamin lakilaki sebesar 23.30\%. Gambar 2 berikut mengilustrasikan sebaran responden berdasarkan tingkatan sekolah dimulai dari SMP, SMA, dan Universitas.

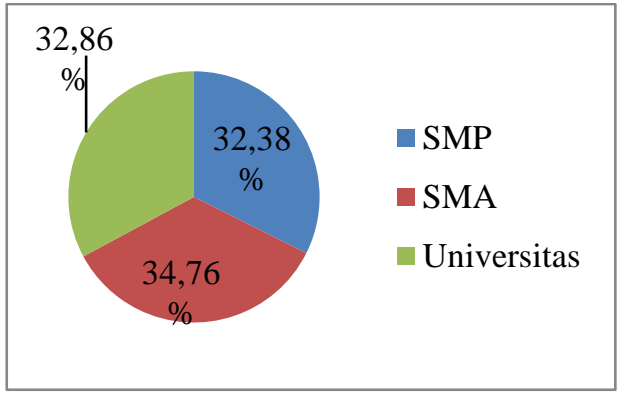

Gambar 2. Persentase responden berdasarkan tingkatan sekolah

Dari gambar 2 terlihat dengan jelas bahwa sebaran responden berdasarkan tingkatan sekolah dapat dikatakan merata, dimana mayoritas responden merupakan siswa dari SMA, yaitu sebanyak $34,76 \%$ kemudian diikuti oleh responden dari universitas sebanyak $32,86 \%$ dan siswa dari SMP sebanyak $32,38 \%$. Lebih lanjut, tabel 1 menunjukkan model summary dari analisis regresi menggunakan program SPSS.

Tabel 1. Model Summary

\begin{tabular}{lcccc}
\hline Model & $\boldsymbol{R}$ & $\boldsymbol{R}$ Square & $\begin{array}{c}\text { Adjusted } \boldsymbol{R} \\
\text { Square }\end{array}$ & $\begin{array}{c}\text { Std. Error of the } \\
\text { Estimate }\end{array}$ \\
\hline 1 & 0.627 & 0.394 & 0.385 & 5.727 \\
\hline
\end{tabular}

a. Predictors: (Constant), E-Learning, age, gender

b. Dependent Variable: Mental health

Tabel 1 mengindikasikan bahwa semua variabel independen yang digunakan dalam analisis, yaitu pembelajaran e-learning $\left(X_{1}\right)$, usia $\left(X_{2}\right)$, dan jenis kelamin $\left(X_{3}\right)$ memiliki korelasi yang positif dan kuat. Dimana koefisien korelasi antara variabel yang diamati dan variabel yang diprediksi adalah sebesar 0,627. Sementara itu, tabel 2 menunjukkan hasil analysis of variance (ANOVA) dalam estimasi model regresi. 
Tabel 2. ANOVA

\begin{tabular}{llccccc}
\hline Model & $\begin{array}{c}\text { Sum of } \\
\text { Squares }\end{array}$ & $\boldsymbol{d} \boldsymbol{f}$ & Mean Square & $\boldsymbol{F}$ & Sig. \\
\hline 1 & Regression & 4386.326 & 3 & 1462.109 & 44.586 & 0.000 \\
& Residual & 6755.431 & 206 & 32.793 & & \\
& Total & 11141.757 & 209 & & & \\
\hline
\end{tabular}

a. Predictors: (Constant), gender, E-Learning, age

b. Dependent Variable: Mental health

Berdasarkan tabel 2, dapat dikethui bahwa nilai signifikansi uji ANOVA pada estimasi regresi adalah 0,000 yang mana lebih kecil dari 0,05 . Hasil ini mengindikasikan bahwa pada level signifikansi 5\%, semua variabel independen yang digunakan (pembelajaran e-learning, umur, dan jenis kelamin) dapat dipercaya dan dapat diandalkan untuk memprediksi variabel dependen (tingkat kesehatan siswa). Perlu diperhatikan bahwa tabel 2 mengukur kemampuan semua variabel independen secara bersamaan dalam memprediksi variabel dependen $(Y$ ) dan bukan kemampuan tiap-tiap variabel independen. Tabel 3 berikut menunjukkan koefisien regresi dari hasil estimasi.

Tabel 3. Coefficients

\begin{tabular}{|c|c|c|c|c|c|c|}
\hline & \multirow[t]{2}{*}{ Model } & \multicolumn{2}{|c|}{$\begin{array}{l}\text { Unstandardized } \\
\text { Coefficients }\end{array}$} & \multirow{2}{*}{$\begin{array}{c}\begin{array}{c}\text { Standardize } \\
\text { d } \\
\text { Coefficients }\end{array} \\
\text { Beta }\end{array}$} & \multirow[t]{2}{*}{$t$} & \multirow[t]{2}{*}{ Sig. } \\
\hline & & $B$ & Std. Error & & & \\
\hline \multirow[t]{4}{*}{1} & (Constant) & 32.230 & 3.132 & & 10.291 & 0.000 \\
\hline & E-Learning $\left(X_{1}\right)$ & 0.859 & 0.079 & 0.610 & 10.879 & 0.000 \\
\hline & Age $\left(X_{2}\right)$ & 0.110 & 0.142 & 0.044 & 0.780 & 0.436 \\
\hline & Gender $\left(X_{3}\right)$ & -1.324 & 0.935 & -0.077 & -1.417 & 0.158 \\
\hline
\end{tabular}

a. Dependent Variable: Mental health

Tabel 3 menunjukkan beberapa penemuan penting dalam penelitian ini. Hasil analisis menunjukkan bahwa ada dua variabel independen yang berpengaruh secara positif terhadap kesehatan mental siswa selama pembelajaran e-learning pada saat pandemi COVID-19, yaitu pembelajaran e-learning $\left(X_{1}\right)$ dan usia responden $\left(X_{2}\right)$. Namun demikian, pengaruh dari kedua variabel independen tersebut terhadap kesehatan mental siswa $(\mathrm{Y})$ memiliki implikasi yang berbeda secara statistika. Dari tabel 3 diketahui bahwa e-learning $\left(X_{1}\right)$ berpengaruh secara positif dan signifikan terhadap kesehatan mental siswa, dimana nilai signifikansi ( $p$-value) adalah 0,000 (lebih kecil dari 0,05). Sedangkan usia siswa berpengaruh secara positif namun tidak signifikan secara statistika terhadap kesehatan mental siswa, dimana nilai signifikansi sama dengan 0,436 (lebih besar dari 0,05). Kemudian, dari tabel 3 juga diketahui bahwa jenis kelamin responden $\left(X_{3}\right)$ memiliki pengaruh yang negatif dan tidak signifikan secara statistika terhadap kesehatan metal siswa ( $Y$ ). 
Lebih lanjut, berdasarkan tabel 3 dapat dilihat dengan jelas bahwa koefisien regresi dari variabel elearning $\left(X_{1}\right)$ adalah sebesar 0,859 yang mengindikasikan bahwa setiap kenaikan 1 poin pada e-learning maka kesehatan mental siswa juga ikut naik sebesar 0,859 poin ketika semua variabel yang lain adalah konstan. Dalam penelitian ini, naiknya kesehatan mental siswa diartikan sebagai tingkat kecemasan yang semakin meningkat.

Berdasarkan hasil jawaban kuesioner ditemukan bahwa mayoritas responden dideteksi mengalami gejala-gejala kesehatan mental yang menurun dan memiliki tingkat kecemasan yang tinggi. Diantaranya, mayoritas responden (sekitar 93.40\%) menyatakan mereka memiliki kekhawatiran yang berlebihan. Kemudian, berdasarkan kuesioner juga ditemukan responden yang menyatakan setuju (41,90\%) dan sangat setuju (43,33\%) bahwa mereka merasa tertekan adanya tugas-tugas sekolah pada masa COVID-19. Hasil juga mengindikasikan bahwa mayoritas responden (92,38\%) tidak memiliki waktu istirahat yang cukup, tidak bisa istirahat secara tenang dan nyaman disebabkan banyaknya tugas-tugas sekolah yang harus diselesaikan dalam waktu yang singkat.

Secara umum, hasil observasi dan wawancara yang berkaitan dengan belajar dari rumah menghasilkan beberapa hal penting, yaitu 1) kurangnya waktu untuk tidur karena banyaknya tugas sekolah; 2) terlalu banyak waktu di depan HP atau laptop yang menyebabkan kurangnya interaksi yang berkualitas dengan keluarga, 3) meningkatnya rasa malas dan motivasi untuk belajar; 4) kesulitan untuk berkonsentrasi dan kehilangan fokus pada pelajaran; 5) Perasaan cepat lelah; dan 6) Kurang bisa membagi waktu. Selain itu, hampir semua responden menyatakan bahwa jaringan internet seringkali menjadi kendala dalam system belajar di rumah. Hasil ini sesuai dengan penelitian Purwanto, dkk (2020) yang menyebutkan bahwa adanya elearning selama pandemi COVID-19 menyebabkan anak-anak merasa jenuh, hilangnya jiwa sosial anak yaitu berkurangnya interaksi dan komunikasi antar teman sebaya dan guru. Sedangkan Fegert, dkk (2020) menjelaskan bahwa adanya pandemi COVID-19 mampu mempengaruhi kesehatan mental pada usia anakanak dan remaja dengan proporsi yang sangat besar yang salah satunya disebabkan kurangnya stabilitas dan kontrol sosial dari teman sebaya dan guru di sekolah.

Kemudian, dari tabel 3 diketahui bahwa koefisien regresi dari variabel usia $\left(X_{2}\right)$ adalah sebesar 0,110 yang menunjukkan bahwa setiap variabel ini naik sebanyak 1 poin maka diprediksi bahwa variabel kesehatan mental meningkat sebanyak 0,110 poin. Sedangkan koefisien regresi pada variabel jenis kelamin (X3) memberikan nilai -1.324 yang mengindikasikan adanya hubungan negatif antara jenis kelamin siswa dan tingkat kesehatan mental mereka. Hasil ini mengindikasikan bahwa untuk siswa perempuan, tingkat kesehatan mental diprediksi akan 1 kali lebih rendah dibandingkan pada siswa laki-laki. Variabel jenis kelamin secara teknis tidak berbeda secara signifikan dari 0 , karena nilai $p$-value lebih besar dari 0,05 . Hasil ini sejalan dengan 
penelitian Afriani \& Lestari (2018) bahwa jenis kelamin (gender) dan usia tidak menunjukkan hubungan dan kontribusi yang signifikan terhadap kesehatan mental.

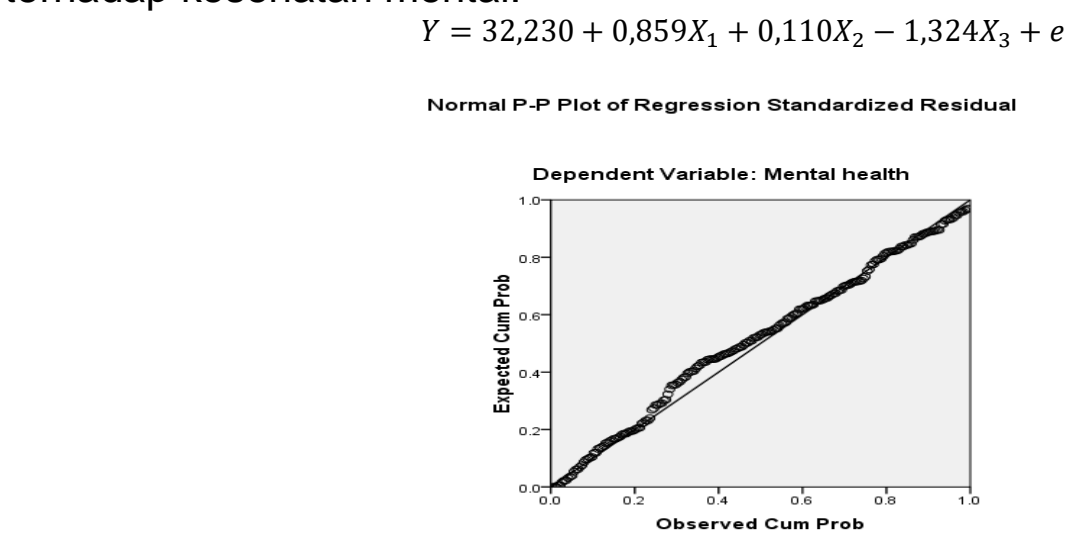

Gambar 3. Garis Regresi Linier

\section{Gambar 3. Garis Regresi Linier}

Kemudian, berdasarkan hasil analisis estimasi regresi pada tabel 3 juga dapat dibangun model regresi linier berganda sebagai berikut:
Gambar 3 mengilustrasikan model regresi yang dibangun dalam penelitian ini, yaitu berupa garis linier yang menunjukkan adanya hubungan positif antara variabel independen (elearning) dan variabel dependen (kesehatan mental). Hal ini berarti jika penggunaan metode e-learning diekspektasi dapat meningkatkan tingkat kecemasan siswa (kesehatan mental yang semakin menurun).

Pembelajaran daring tidaklah mudah untuk dilakukan, sehingga hal ini menjadi tantangan bagi para pendidik dan peserta didik serta orang tua. Meskipun secara fakta bahwa pembelajaran daring mampu memberikan tekanan bagi para siswa, namun dengan adanya bimbingan dari orang tua dan kerjasama yang baik antara orang tua dan guru akan dapat mewujudkan pembelajaran daring yang efektif. Selain itu, beberapa saran dari responden agar pembelajaran daring lebih menyenangkan adalah: interaksi antara guru dan siswa lebih dimaksimalkan, diskusi dengan antar teman, materi yang diberikan dapat berupa video dan animasi yang menarik, memberikan reward kepada siswa yang aktif, menggunakan metode quiz dan games, dan memberikan fasilitas yang memadai seperti kuota internet. Beberapa kelebihan dari pembelajaran daring adalah: lebih fokus belajar dan mengerjakan tugas, memiliki wawasan yang lebih luas dan lebih cepat, meningkatkan keterampilan IT, fleksibilitas waktu, bebas berkreasi dan aktif mencari materi sendiri, lebih disiplin waktu karena tugas yang diberikan dibatasi dengan waktu, lebih mandiri dan kreatif, dan memiliki waktu yang lebih banyak dengan keluarga.

Secara keseluruhan, hasil penelitian ini mengemukakan bahwa e-learning memiliki hubungan yang positif dan signifikan secara statistika terhadap kesehatan mental siswa selama pandemi COVID-19. Proses pembelajaran e-learning yang dilakukan secara terus menerus diekspektasikan dapat menurunkan kesehatan mental siswa. Berbagai gejala penurunan kesehatan mental 
siswa diketahui dari banyaknya siswa yang mengalami kecemasan tingkat tinggi, memiliki rasa khawatir yang berlebihan. Selain itu, kebanyakan siswa juga diketahui merasa tertekan akibat banyaknya tugas-tugas yang diberikan oleh guru/dosen yang juga menyebabkan mereka kekurangan waktu untuk beristirahat. Dengan demikian, perlu disusun strategi yang terbaik dan terstruktur untuk mengatasi gangguan kesehatan mental siswa selama pandemi COVID-19.

\section{SIMPULAN}

Hasil analisis menunjukkan
bahwa: 1) e-learning memiliki pengaruh yang positif dan signifikan mental; dan 3) gender memiliki pengaruh yang negatif dan tidak signifikan terhadap kesehatan mental. Untuk penelitian selanjutnya dapat dilakukan dengan menggunakan terhadap kesehatan mental; 2) usia memiliki pengaruh yang positif dan tidak signifikan terhadap kesehatan ukuran sampel yang lebih besar untuk mendapatkan hasil estimasi yang lebih akurat. Selain itu, wilayah penelitian yang lebih luas juga dapat dipertimbangkan.

\section{DAFTAR PUSTAKA}

Afriani, A. \& Lestari, N. M. (2018). Pengaruh Jenis Kelamin, Usia, dan Religiusitas terhadap Kesehatan Mental Remaja. Philanthropy: Journal of Psychology. DOI: 10.26623/philanthropy.v1i2.1065

Derogatis, L.R. (1993). The Brief Symptom Inventory:

Administration, Scoring, and Procedures Manual. Minneapolis, MN: National Computer Systems.

Fegert, J. M., Vitiello, B., Plenner, P. L., \& Clemens, V. (2020). Challenges And Burden Of The Coronavirus 2019 (Covid-19) Pandemic For Child And Adolescent Mental Health: a Narrative Review To Highlight Clinical And Research Needs In The Acute Phase And The Long Return To Normality. Child Adolesc Psychiatry Ment Health. $\begin{array}{lll}\text { Vol } & 14 & \text { (20): } 1-11 .\end{array}$ https://doi.org/10.1186/s13034020-00329-3.
IASC. (2020). Addressing Mental Health and Psychosocial Aspects of COVID-19 Outbreak. https://interagencystandingcomm ittee.org/system/files/202003/IASC\%20Interim\%20Briefing $\% 20$ Note\%20on\%20COVID19\%200utbreak\%20Readiness \%20and\%20Response\%200per ations\%20-\%20MHPSS 0.pdf.

Khan, K., Parsonage, M., \& Stubbs, J. (2014). Investing in children's mental health. CentreForum's Mental Health Commission. https://www.crisiscareconcordat. org.uk/wpcontent/uploads/2015/02/investin $g$ in childrens mental health.pd f

KPAI. (2020). "Ada 246 Aduan di KPAI soal Belajar Daring, Siswa Keluhkan Tugas MenumpukKuota". Diakses dalam https://www.kpai.go.id/berita/ada -246-aduan-di-kpai-soal-belajardaring-siswa-keluhkan-tugasmenumpuk-kuota. 
Mahmudah, U. (2020). Metode Statistika: Step by Step. Pekalongan: Penerbit NEM.

Mekonnen, H., Medhin, G., Tomlinson, M., Alem, A., Price, M., \& Hanlon, C. (2020). Impact Of Child Emotional And Behavioural Difculties On Educational Outcomes Of Primary School Children In Ethiopia: a Population-Based Cohort Study. Child Adolesc Psychiatry Ment Health. Vol. 14 (22): 1-10. https://doi.org/10.1186/s13034020-00326-6.

Purwanto, A., Pramono, R., Asbari, M., Santoso, P. B., Wijayanti, L. M., Hyun, C. C., Putri, R. S. (2020). Studi Eksploratif Dampak Pandemi COVID-19 Terhadap Proses Pembelajaran Online di Sekolah Dasar. Journal of Education, Psychology, and Counseling. Vol 2 (1): 1-12.

Stagman, S., \& Cooper, J. L. (2010). Children's Mental Health What Every Policymaker Should Know. National Center for Children in Poverty (NCCP). http://www.nccp.org/publications/ pdf/text 929.pdf

WHO. (2020). Helping Children Cope With Stress During The 2019-
Ncov

Outbreak.

https://www.who.int/docs/defaultsource/coronaviruse/helpingchildren-cope-with-stressprint.pdf?sfvrsn=f3a063ff 2 .

WHO. (2011). Maternal, Child And Adolescent Mental Health. https://applications.emro.who.int/ dsaf/dsa1214.pdf.

UNICEF. (2020a). Covid-19 and Children in Indonesia. https://www.unicef.org/indonesia/ reports/covid-19-and-children-inindonesia.

UNICEF. (2020b). COVID-19: Bekerja dengan dan Untuk Anak Muda. https://www.unicef.org/indonesia/ sites/unicef.org.indonesia/files/20 20-06/COVID-19-Bekeriadengan-dan-untuk-anak-muda2020.pdf

UNICEF. (2019). Protection of Children during the Coronavirus Disease (COVID-19) Pandemic: Technical Note. https://www.unicef.org/document s/technical-note-protectionchildren-coronavirus-disease2019-covid-19-pandemic. 